\title{
SUGAR BEET PRODUCTIVITY AS AFFECTED BY FOLIAR SPRAYING WITH METHANOL AND BORON
}

\author{
ABIDO W.A.E.* \\ Agronomy Department, Faculty of Agriculture, Mansoura University, Egypt. \\ *Corresponding Author: Email- madawy78@mans.edu.eg
}

Received: November 05, 2012; Accepted: November 20, 2012

\begin{abstract}
Two field experiments were carried out at Kafr El-Garayda Village, Bialla Center, Kafr El-Sheikh Governorate, Egypt during 2010/2011 and 2011/2012 seasons to study the effect of methanol and boron foliar spraying on growth, yield and quality of sugar beet. This aimed to study four aqueous methanol solutions control without $0,15,30$ and $45 \%$ (v/v) sprayed three times during growth stages which occupied the vertical plots and four boron concentrations control without 0, 40, 80 and 120 ppm as boric acid applied as foliar spraying at two times during growth season and assigned in the horizontal plots.
\end{abstract}

Results indicated that foliar application of 30\% methanol solution significantly increased all studied characters i.e. total chlorophyll, leaf area/plant, foliage and root fresh weight, foliage and root length and root diameter, total soluble solids, sucrose and apparent purity percentages, root, top and sugar yields/ha, whereas harvest index was decreased. Moreover, increasing methanol concentration to $45 \%$ tended to decrease all above mentioned characters. Application of $80 \mathrm{ppm}$ boron significantly improved root yield and its attributes and root quality, on contrarily harvest index was decreased. Maximum top, root, sugar yields/ha and root quality produced by foliar spraying of $30 \%$ methanol and $80 \mathrm{ppm}$ boron.

Keywords- Sugar beet, (Beta vulgaris, L.), methanol, Boron, yield and quality

Citation: Abido W.A.E. (2012) Sugar Beet Productivity as Affected by Foliar Spraying with Methanol and Boron. International Journal of Agriculture Sciences, ISSN: 0975-3710 \& E-ISSN: 0975-9107, Volume 4, Issue 7, pp-287-292.

Copyright: Copyright@2012 Abido W.A.E. This is an open-access article distributed under the terms of the Creative Commons Attribution License, which permits unrestricted use, distribution and reproduction in any medium, provided the original author and source are credited.

\section{Introduction}

In Egypt, there is a gap between sugar consumption and production due to steady increases in population and average consumption of sugar beside limited cultivated area of both sugar beet (Beta vulgaris, L) and sugar cane. To increase sugar beet productivity per unit area sugar beet plants subjected to i.e. methanol and boron foliar fertilization since production of biomass by plants depends to great extent on environmental factors i.e. water supply, air temperature and carbon dioxide concentration in the canopy [24]. Increasing the dioxide carbon content in the air increase yield and plants accumulated more carbohydrates because almost $90 \%$ of plant dry matter weight is resulted from $\mathrm{CO}_{2}$ assimilation during photosynthesis $[1,12,15,17]$. Photo respiration can be minimized with methanol spray, since $25 \%$ of carbon wastes during photorespiration [6]. Similar conclusions were reported by $[2,18,23,25]$. Moreover, Sadeghi-Shoae M., et al [20] concluded that foliar application of methanol at $14 \%$ increased root yield to $25 \%$ in comparison with the control.

Foliar spraying of boron increase root yield since roots absorbed boric acid and its uptake depends on soil pH and soil boron content [8] due to chloroplast formation and sink limitations [22] and changes in cell wall which effects of boron deficit and led to secondary effects in plant metabolism, development and growth [16]. Gobarah Mirvat E., et al [10] revealed that application of boron rates from zero up to $1.5 \mathrm{Kg} / \mathrm{acre}$ increased root length, diameter and root yield. Moreover, increasing boron fertilizer up to $2.0 \mathrm{Kg} / \mathrm{acre}$ resulting highest sugar yield (6.611 ton/acre). Sucrose and juice purity percentages were also increased by adding higher concentration of boron might be attributed to decrease $\mathrm{Na}$ and $\mathrm{K}$ uptake in root juice. Similar results were recorded by $[7,9,13,14]$. Armin M. and Asgharipour M.R. [3] indicated that highest root yield and sucrose concentration were obtained by spraying with $12 \%$ boric acid.

Therefore, this study was undertaken to study the response of sugar beet cv. Gloria to foliar application with methanol and boron to achieve maximum root productivity and its quality.

\section{Materials and Methods}

Two field experiments were conducted at Kafr El-Garayda Village, Bialla Center, Kafr El-Sheikh Governorate, Egypt during 2010/2011 and 2011/2012 seasons. The main objectives of this study were aimed to study the effect of foliar application with methanol and boron concentrations on sugar beet (Beta vulgaris L.) cv. Gloria productivity and quality.

Two field experiments were laid-out in strip plot design with four 
replications. The vertical plots were occupied by four concentrations of methanol i.e. control without $0,15,30$ and $45 \%(\mathrm{v} / \mathrm{v})$ methanol and each solution contained $0.2 \%$ glycine to reduce the probability of methanol toxicity [19]. These solutions were sprayed on sugar beet foliage three times every two week. The first foliar application was applied at 80 days after planting. The horizontal plots were assigned to four foliar application of boron in the form of boric acid i.e. control without $0,40,80$ and $120 \mathrm{ppm}$ these solutions were sprayed on foliage parts of sugar beet two times (50 and 70 days after planting). The foliar solutions volume was to $200 \mathrm{~L} / \mathrm{ha}$ conducted by hand sprayer. The soil of experimental site was clayey with an electrical conductivity $(E C)$ of $1.65 \mathrm{dS} / \mathrm{m}$ and a $\mathrm{pH}$ of 7.88 .

Each plot consist 5 ridges, each of $60 \mathrm{~cm}$ apart and $3.5 \mathrm{~m}$ long, comprising an area of $10.5 \mathrm{~m}^{2}$ (1/400 ha). The preceding summer crop was rice (Oryza sativa L.) in both seasons. The experimental soil was fertilized with $71.4 \mathrm{~kg} \mathrm{P}_{2} \mathrm{O}_{5} / \mathrm{ha}$ in the form of calcium superphosphate $\left(15.5 \% \mathrm{P}_{2} \mathrm{O}_{5}\right)$ during soil preparation, nitrogen in the form of ammonium nitrate $(33.0 \% \mathrm{~N})$ at a rate of $297.5 \mathrm{~kg} \mathrm{~N} / \mathrm{ha}$ added at four equal doses before second, third, fourth and fifth irrigations and potassium at the rate of $114.24 \mathrm{~kg} \mathrm{~K} \mathrm{~K}_{2} \mathrm{O} / \mathrm{ha}$ in the form of potassium sulphate $\left(48 \% \mathrm{~K}_{2} \mathrm{O}\right)$ in two equal portions added before second and fourth irrigations. Sowing took place on September $15^{\text {th }}$ and $18^{\text {th }}$ in the first and second seasons, respectively. Sugar beet balls were hand sown (3-5 balls/hill) using dry planting method on one side of the ridge and hills $20 \mathrm{~cm}$ apart. Experimental plots were irrigated immediately after planting, then irrigation frequently every 10 days. Plants were thinned after 30 days from planting to one plant/hill to produce 83300 plants/ha. Plants were kept free from weeds, which were manually controlled by hoeing two times before the second and third irrigations. In general, the agricultural practices for growing sugar beet according to Ministry of Agriculture recommendations were followed.

\section{Studied Characters}

\section{Growth, Yield Component and Quality Characters}

A representative samples were taken during the growth period (150 days from planting), i.e. five guarded plants were chosen at random from second and fourth ridges of each plot to determinate the following traits:

1. Total chlorophyll (SPAD): Leaf chlorophyll content was assessed by SPAD-502 (Minolta Co. Ltd., Osaka, Japan).

2. Leaf area/plant $\left(\mathrm{cm}^{2}\right)$ : It was determined using Field Portable Leaf Area Meter AM-300 (Bio-Scientific, Ltd., Great Amwell, Herforshire, England).

At maturity (190 DAP) five guarded plants were chosen at random from the second and fourth ridges of each plot to determine yield components and quality characters as follows:

3. Foliage fresh weight (gm/ plant).

4. Foliage length $(\mathrm{cm})$.

5. Root fresh weight (gm/plant).

6. Root length $(\mathrm{cm})$.

7. Root diameter (cm).

8. Total soluble solids (TSS \%) in roots was measured in juice of fresh roots by using Hand Refractometer

9. Sucrose percentage (\%) was determined Polarimetrically on lead acetate extract of fresh macerated roots according to the method of Carruthers A. and Oldfield J.E.T. [5].

10. Apparent purity percentage (\%): It was determined as a ratio between sucrose $\%$ and TSS $\%$ of roots as the method outlined by Carruthers A. and Oldfield J.E.T. [5].

Yield of three inner ridges of each plot were harvested and cleaned. Roots and tops were separated and weighted to estimate:

11. Root yield (ton/ha).

12. Top yield (ton/ha).

13. Sugar yield (ton/ha): was calculated by multiplying root yield (ton/ha) by sucrose $\%$.

14. Harvest index $(\mathrm{HI})$ : was calculated by using the following equation:

$$
\mathrm{HI}=\frac{\text { Root yield (ton/ha) }}{\text { Top yield (ton/ha) + Root yield (ton/ha) }}
$$

All obtained data were statistically analyzed according to the technique of analysis of variance (ANOVA) for the strip plot design as published by Gomez and Gomez [11] by using by using MSTAT-C Statistical package MSTAT-C with (MGRAPH version 2.10). Least Significant Difference (LSD) method was used to test the differences between treatment means at 5 and $1 \%$ level of probability [21].

\section{Results and Discussion}

\section{A. Effect of Methanol Concentrations}

Results showed that all studied characters i.e. total chlorophyll, leaf area/plant, foliage fresh weight, foliage length, root fresh weight, root length, root diameter [Table-1], total soluble solids, sucrose, apparent purity percentages, root yield, top yield, sugar yield and harvest index [Table-2] were significantly affected by spraying $30 \%$ methanol in both seasons and then decreased due to application of $45 \%$ methanol. It could be stated that foliar application of $30 \%$ methanol solution significantly increased all studied growth, yield and quality of sugar beet traits and consequently produced the highest values. It could be noticed that applying 30\% methanol caused significant increases in total chlorophyll, leaf area/plant, foliage fresh weight, foliage length, root fresh weight, root length, root diameter, total soluble solids, sucrose (\%), apparent purity percentages, root yield/ha, top yield/ha and sugar yield/ha by $12.38,8.95,40.92,10.53,17.20,18.32,19.53,5.17,10.8,7.76$, $16.31,30.53$ and $25.5 \%$, respectively as an average of both seasons compared with control treatment. Harvest index was decreased by $4.04 \%$ as an average of both season compared to control treatment. Generally, foliar application of $45 \%$ methanol solution came in the second rank after $30 \%$ methanol and then followed by foliar application of $15 \%$ methanol solution, whereas control treatment recorded the lowest values for all studied characters, except (HI) was the higher one. The favorable effect of $30 \%$ methanol might be due to the treating plants with methanol could be enhance their net photosynthesis, therefore improving the yield. Nonomura and Benson [19] showed that methanol reduces the plants photorespiration and the rapidly oxidized. Also methanol 
causes to delay senescence in leaves and influences on ethylene production in plant which this causes to increase photo synthesis activity [25]. Moreover, Zbieć I., et al [24] observed that yield of roots increased by $10 \%$ using 20 or $30 \%$ methanol solutions. These results are in accordance with those reported by $[17,18,20]$.

\section{B. Effect of Boron Concentrations}

A significant effect was detected due to boron concentrations application on total chlorophyll, leaf area/plant, foliage fresh weight, foliage length, root fresh weight, root length, root diameter [Table1], total soluble solids, sucrose, apparent purity percentages, root yield, top yield, sugar yield and harvest index [Table-2] in both seasons. Increasing boron concentrations up to 80 ppm significantly increased all studied traits. While, application boron at $120 \mathrm{ppm}$ came in the second rank with respect to these characters. Foliar spraying of boron at $80 \mathrm{ppm}$ increased total chlorophyll, leaf area/ plant, foliage fresh weight, foliage length, root fresh weight, root length, root diameter, total soluble solids, sucrose (\%), apparent purity percentages, root yield/ha, top yield/ha and sugar yield/ha by $12.77,9.53,31.34,10.83,9.72,16.68,15.24,2.48,9.75,7.39$, $11.27,19.01$ and $20.14 \%$, respectively as an average of two seasons compared with the control treatment. While harvest index decreased by $1.91 \%$ as an average of two seasons compared to the control treatment. The positive effect of boron may be due to the boron role in cell elongation where, in case of boron deficiency, plant leaves were smaller, stiff and thick [4]. Gobarah Mirvat E. and Mekki B.B. [10] indicated that root yield, sucrose and juice purity percentage increased by boron addition which may be attributed to decrease $\mathrm{Na}$ and $\mathrm{K}$ uptake in root juice. These results are in harmony with those obtained by $[3,7,9,13]$.

Table 1- Means of total chlorophyll, leaf area/plant, foliage fresh weight, foliage length, root fresh weight, root length and diameter as affected by methanol, boron concentrations and their interaction during 2010/2011 and 2011/2012 seasons

\begin{tabular}{|c|c|c|c|c|c|c|c|c|c|c|c|c|c|c|}
\hline \multirow{3}{*}{$\begin{array}{l}\text { Treatments } \\
\text { Seasons }\end{array}$} & \multicolumn{14}{|c|}{ Characters } \\
\hline & \multirow{2}{*}{\multicolumn{2}{|c|}{$\begin{array}{l}\text { Total chlorophyll (SPAD } \\
2010 / 2011 \quad 2011 / 2012\end{array}$}} & \multirow{2}{*}{\multicolumn{2}{|c|}{$\begin{array}{l}\text { Leaf area/plant }\left(\mathrm{cm}^{2}\right) \\
2010 / 20112011 / 2012\end{array}$}} & \multirow{2}{*}{\multicolumn{2}{|c|}{$\begin{array}{l}\text { Foliage fresh weight }(\mathrm{g}) \\
2010 / 2011 \quad 2011 / 2012\end{array}$}} & \multirow{2}{*}{\multicolumn{2}{|c|}{$\begin{array}{l}\text { Foliage length }(\mathrm{cm}) \\
2010 / 20112011 / 2012\end{array}$}} & \multirow{2}{*}{\multicolumn{2}{|c|}{$\begin{array}{l}\text { Root fresh weight }(\mathrm{g}) \\
2010 / 2011 \quad 2011 / 2012\end{array}$}} & \multirow{2}{*}{\multicolumn{2}{|c|}{$\begin{array}{l}\text { Root length }(\mathrm{cm}) \\
2010 / 20112011 / 2012\end{array}$}} & \multicolumn{2}{|c|}{ Root diameter (cm) } \\
\hline & & & & & & & & & & & & & 2010/201 & 2011/2012 \\
\hline Control without 0 & 42.08 & 42.86 & 3321.6 & 3372.9 & 229.91 & 238.33 & 41.02 & 41.8 & 843.75 & 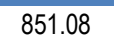 & 21.71 & 22.98 & 11.6 & 11.92 \\
\hline Methano & 44.4 & & & 09.5 & & & & & & & & & & 3.57 \\
\hline Methanol 30\% & 47.91 & 49.04 & 3647 & 3707 & 38 & 407.91 & 46.12 & 47.57 & 1025 & 1022.16 & 26.89 & 27.82 & 4.25 & 14.99 \\
\hline Methanol 45\% & 45 & 46.12 & 3534.8 & 3559.5 & 331.66 & 348.33 & 44.02 & 45.02 & 931.66 & 927.25 & 25.71 & 26.27 & 13.66 & 13.92 \\
\hline F. test & ** & ** & ** & ** & ** & ** & $* *$ & $* *$ & ** & ** & $* *$ & ** & $* *$ & $* *$ \\
\hline LSD at $5 \%$ & 0.72 & 0.39 & 36.3 & 36.3 & 24.7 & 15.42 & 0.86 & 0.85 & 7.94 & 23.4 & 0.54 & 0.51 & 0.32 & 0.28 \\
\hline \multicolumn{15}{|c|}{ B- Boron concentration (ppm) } \\
\hline Control without 0 & & 42.47 & 3284.1 & 3336.2 & 259.5 & 265 & 40.76 & 41.58 & 867.08 & & 22. & 23. & 11 & 12.41 \\
\hline Boron 40 ppm & 44.46 & 45.56 & 3433.3 & 3510.4 & 285 & 296.66 & 43.4 & 44.52 & 905.83 & 915.83 & 23.6 & 25.35 & 12.96 & 13.34 \\
\hline Boron 80 ppm & 47.31 & 48.26 & 3641.6 & 3676.6 & 374.58 & 389.58 & 45.75 & 46.6 & 975 & 961.66 & 26.81 & 28.15 & 14.1 & 14.46 \\
\hline Boron 120 ppm & 45.99 & 47.06 & 3561.5 & 3625.8 & 318.75 & 347.08 & 44.34 & 45.77 & 958.75 & 956.58 & 25.57 & 26.32 & 13.72 & 14.19 \\
\hline F. test & $* *$ & 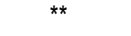 & & & $* *$ & ** & & ** & $* *$ & ** & $* *$ & ${ }^{* *}$ & $* *$ & $* *$ \\
\hline LSD at $5 \%$ & 0.59 & 0.44 & 34 & 27.1 & 26.49 & 17.38 & 0.74 & 0.31 & 10.82 & 10.01 & 0.46 & 0.23 & 0.48 & 0.46 \\
\hline C- Interaction: & $* *$ & $\star *$ & ** & $\star *$ & $* *$ & $\star \star *$ & $* *$ & $* *$ & $\star *$ & $* *$ & $\star *$ & $\star *$ & $\star *$ & $\star \star *$ \\
\hline
\end{tabular}

Table 2- Means of total soluble solids (TSS), sucrose and apparent purity percentages, root, top and sugar yields and harvest index (HI) as affected by methanol, boron concentrations and their interaction during 2010/2011 and 2011/2012 seasons.

\begin{tabular}{|c|c|c|c|c|c|c|c|c|c|c|c|c|c|c|}
\hline \multirow{3}{*}{$\begin{array}{l}\text { Treatments } \\
\text { Seasons }\end{array}$} & \multicolumn{14}{|c|}{ Characters } \\
\hline & \multicolumn{2}{|c|}{ Total soluble solids (TSS\%) } & \multicolumn{2}{|c|}{ Sucrose $(\%)$} & \multicolumn{2}{|c|}{ Apparent Purity (\%) } & \multicolumn{2}{|c|}{ Root yield (ton/ha) } & \multicolumn{2}{|c|}{ Top yield (ton/ha) } & \multicolumn{2}{|c|}{ Sugar yield (ton/ha) } & \multicolumn{2}{|c|}{ Harvest index (HI) } \\
\hline & $2010 / 2011$ & $2011 / 2012$ & $2010 / 2011$ & $2011 / 2012$ & $\begin{array}{r}2010 / 2011 \\
\text { A- Meth }\end{array}$ & $\begin{array}{l}2011 / 2012 \\
\text { inol conce }\end{array}$ & $\begin{array}{l}2010 / 2011 \\
\text { entrations ( }\end{array}$ & $2011 / 2012$ & 2010/2011 & $2011 / 2012$ & $2010 / 2011$ & $2011 / 2012$ & 2010/2011 & $2011 / 2012$ \\
\hline Methanol $15 \%$ & 22.18 & 22.6 & 17.1 & 17.4 & 77.11 & 76.98 & 59.081 & 60.352 & 16.686 & 17.283 & 10.117 & 10.517 & 0.78 & 0.778 \\
\hline Methanol 30\% & 22.8 & 23.11 & 18.45 & 18.75 & 80.87 & 81.12 & 67.882 & 69.595 & 21.284 & 22.621 & 12.554 & 13.097 & 0.762 & 0.755 \\
\hline Methanol 45\% & 22.7 & 22.73 & 18.05 & 18.2 & 79.49 & 80.04 & 62.682 & 63.912 & 19.12 & 19.682 & 11.335 & 11.654 & 0.767 & 0.765 \\
\hline F. test & ** & ** & ** & ** & ** & ** & ** & ** & ** & ** & ** & ** & ** & ** \\
\hline LSD at $5 \%$ & 0.23 & 0.24 & 0.34 & 0.33 & 1.39 & 1.55 & 0.381 & 0.376 & 0.143 & 0.269 & 0.121 & 0.127 & 0.003 & 0.007 \\
\hline \multicolumn{15}{|c|}{ B- Boron concentration (ppm) } \\
\hline Control without 0 & 22.04 & 22.28 & 16.42 & 16.7 & 74.49 & 74.93 & 57.398 & 58.35 & 15.527 & 16.638 & 9.443 & 9.7627 & 0.787 & 0.779 \\
\hline Boron 40 ppm & 22.24 & 22.5 & 17.45 & 17.72 & 78.41 & 78.7 & 61.758 & 62.696 & 18.173 & 18.692 & 10.819 & 11.152 & 0.774 & 0.772 \\
\hline Boron 80 ppm & 22.63 & 22.82 & 18.2 & 18.5 & 80.36 & 81 & 64.359 & 66.111 & 19.565 & 20.141 & 11.759 & 12.295 & 0.768 & 0.768 \\
\hline Boron 120 ppm & 22.45 & 22.7 & 17.98 & 18.17 & 80.08 & 80.01 & 63.346 & 64.455 & 18.844 & 19.585 & 11.414 & 11.738 & 0.771 & 0.768 \\
\hline F. test & $* *$ & $\star *$ & $* *$ & ** & ** & ** & ** & ** & ** & ** & ** & ** & ** & $* *$ \\
\hline LSD at $5 \%$ & 0.19 & 0.05 & 0.29 & 0.2 & 1.15 & 0.79 & 0.354 & 0.197 & 0.278 & 0.243 & 0.083 & 0.068 & 0.007 & 0.006 \\
\hline
\end{tabular}

\section{Interactions Effect}

Regarding the interaction effect between methanol and boron concentrations. The results clearly showed a significant effect on total chlorophyll [Fig-1], leaf area/plant [Fig-2], foliage fresh weight [Fig-
3], foliage length [Fig-4], root fresh weight [Fig-5], root length [Fig6], root diameter [Fig-7], root yield [Fig-8], top yield [Fig-9], sugar yield [Fig-10] and harvest index [Fig-11] in both season as well as sucrose [Fig-12] and apparent purity [Fig-13] in the second season only. 


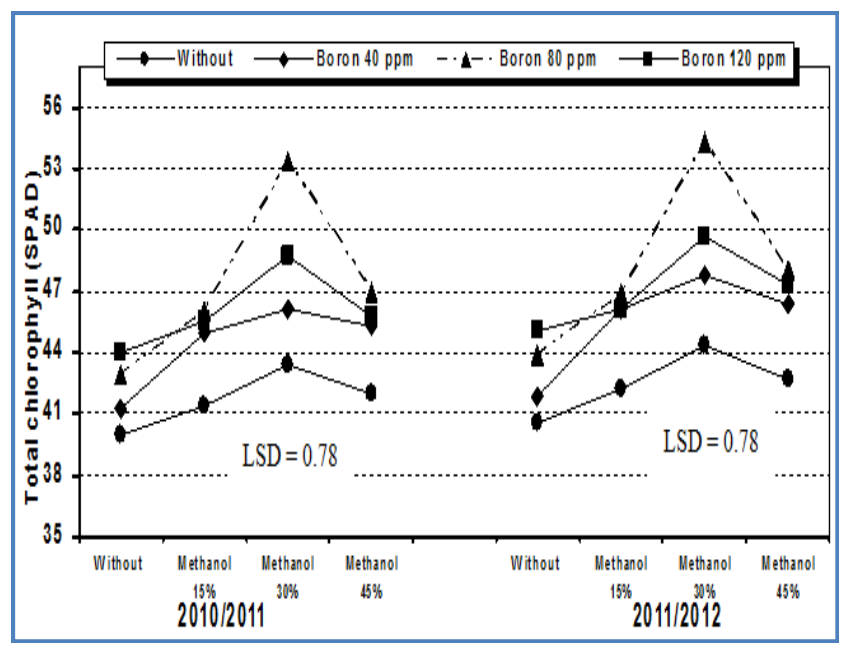

Fig. 1- Total chlorophyll (SPAD) of sugar beet as affected by the interaction between methanol and boron treatments during 2010/2011 and 2011/2012 seasons

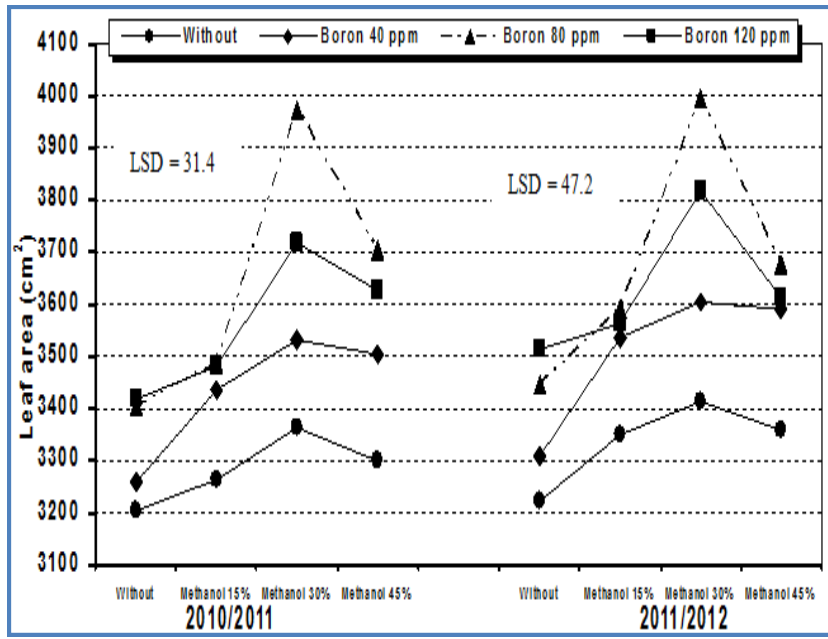

Fig. 2- Leaf area $\left(\mathrm{cm}^{2}\right)$ of sugar beet as affected by the interaction between methanol and boron treatments during 2010/2011 and 2011/2012 seasons

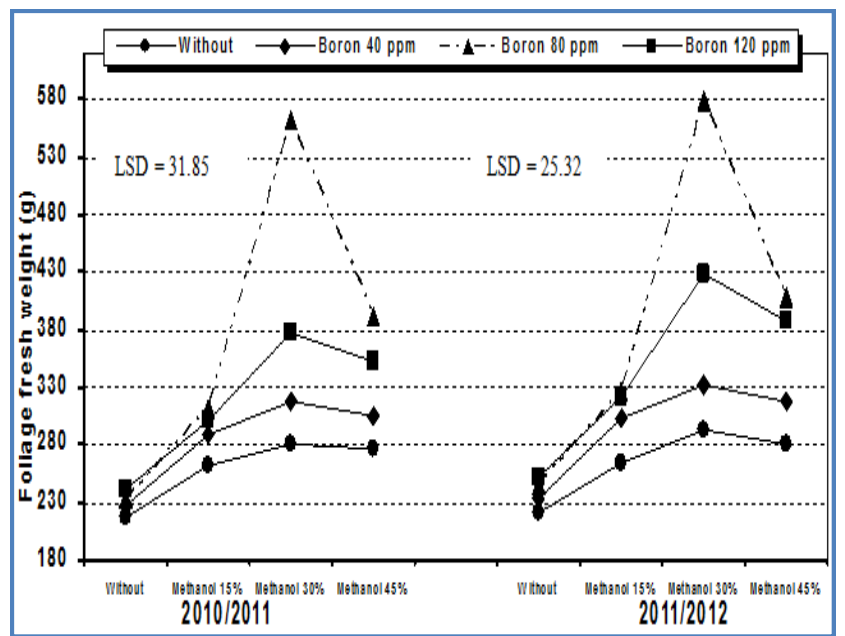

Fig. 3- Foliage fresh weight $(\mathrm{g})$ of sugar beet as affected by the interaction between methanol and boron treatments during 2010/2011 and 2011/2012 seasons

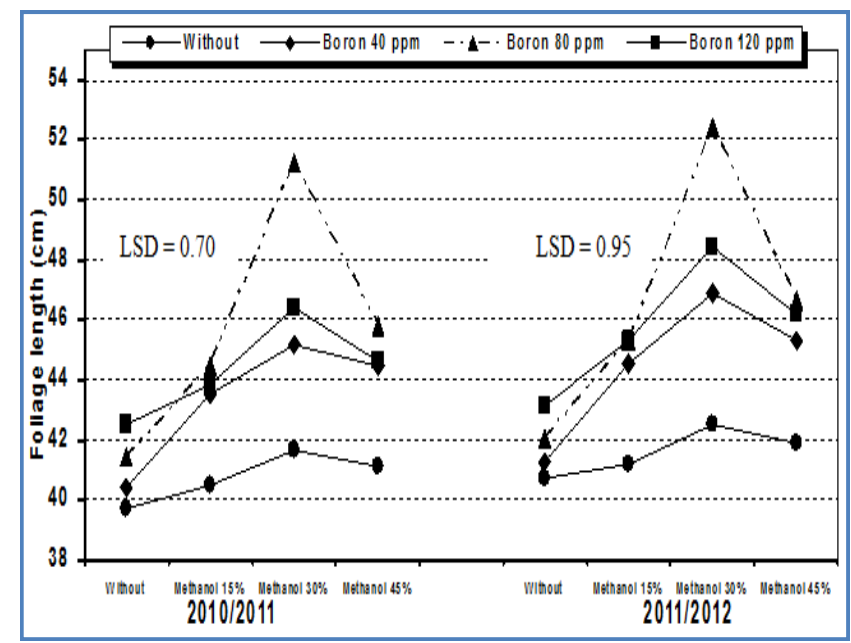

Fig. 4- Foliage length $(\mathrm{cm})$ of sugar beet as affected by the interaction between methanol and boron treatments during 2010/2011 and 2011/2012 seasons

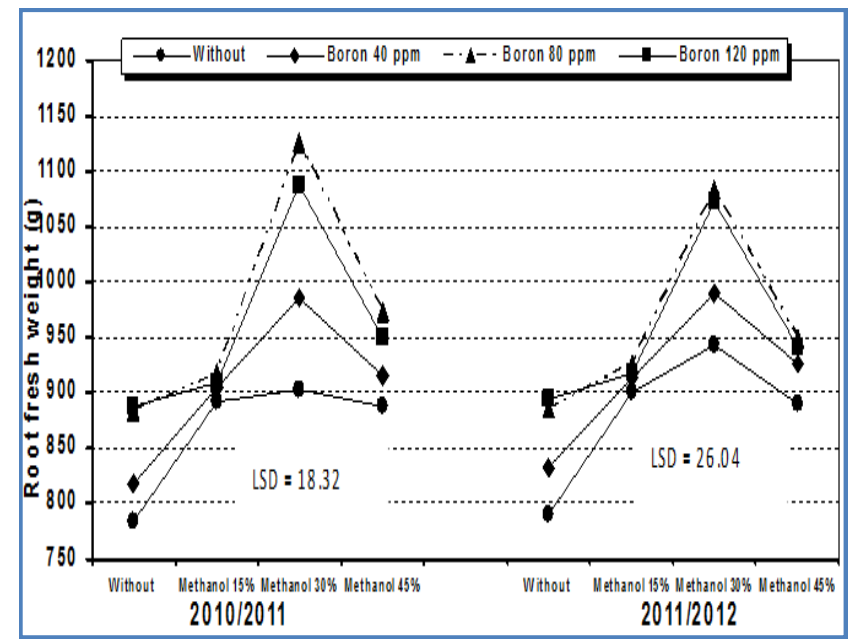

Fig. 5- Root fresh weight (g) of sugar beet as affected by the interaction between methanol and boron treatments during 2010/2011 and 2011/2012 seasons

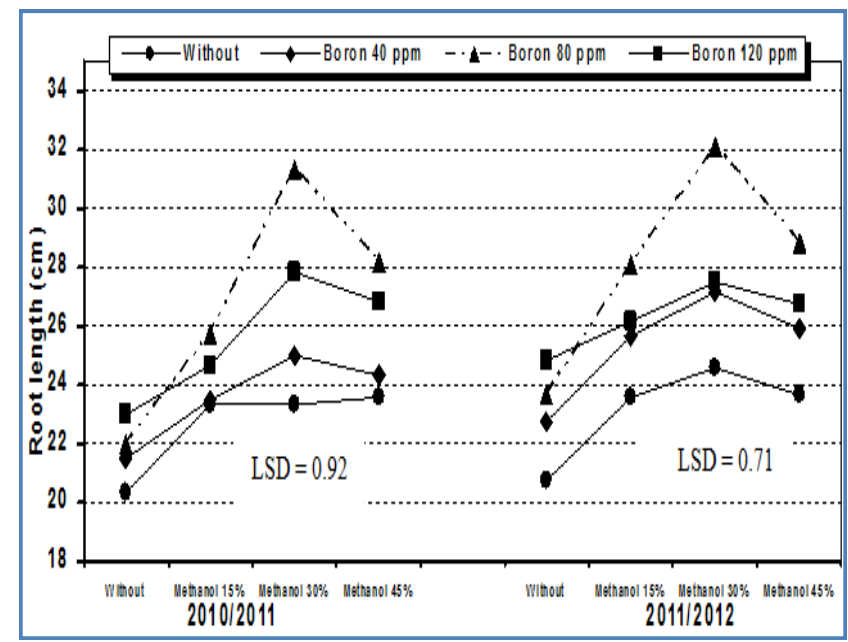

Fig. 6- Root length (cm) of sugar beet as affected by the interaction between methanol and boron treatments during 2010/2011 and 2011/2012 seasons 


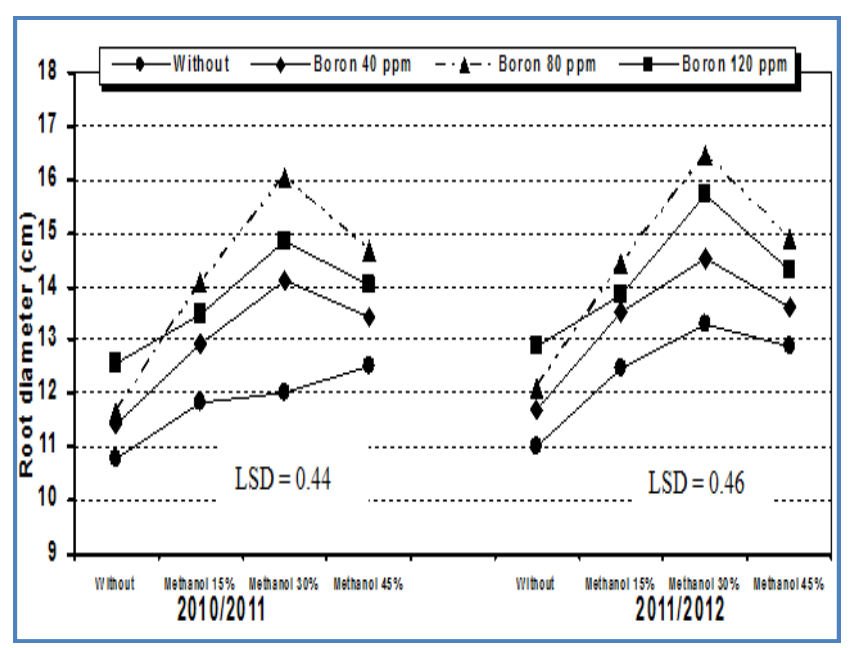

Fig. 7- Root diameter (cm) of sugar beet as affected by the interaction between methanol and boron treatments during 2010/2011 and 2011/2012 seasons.

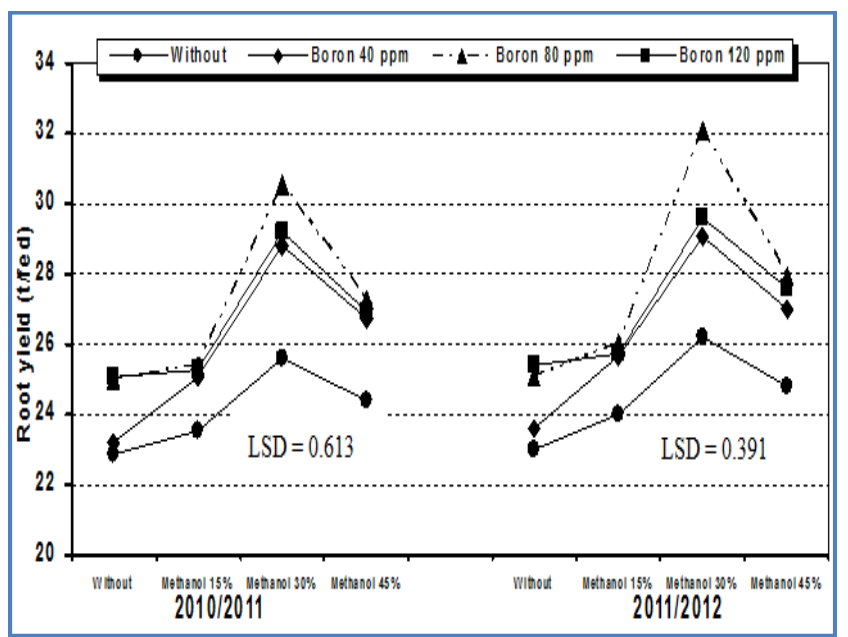

Fig. 8- Root yield (t/fed) of sugar beet as affected by the interaction between methanol and boron treatments during 2010/2011 and 2011/2012 seasons

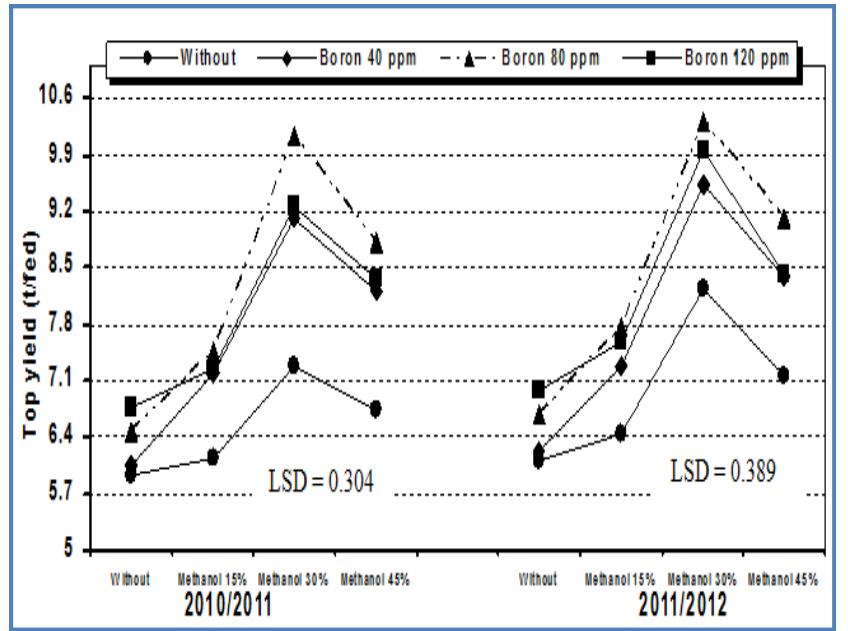

Fig. 9- Top yield (t/fed) of sugar beet as affected by the interaction between methanol and boron treatments during 2010/2011 and 2011/2012 seasons.

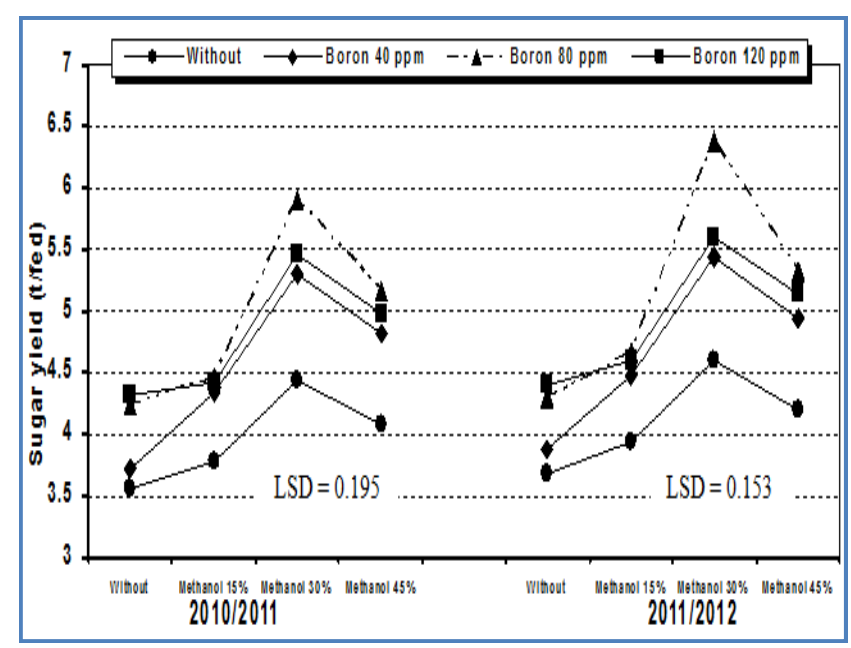

Fig. 10- Sugar yield ( $\mathrm{t} / \mathrm{fed}$ ) of sugar beet as affected by the interaction between methanol and boron treatments during 2010/2011 and 2011/2012 seasons.

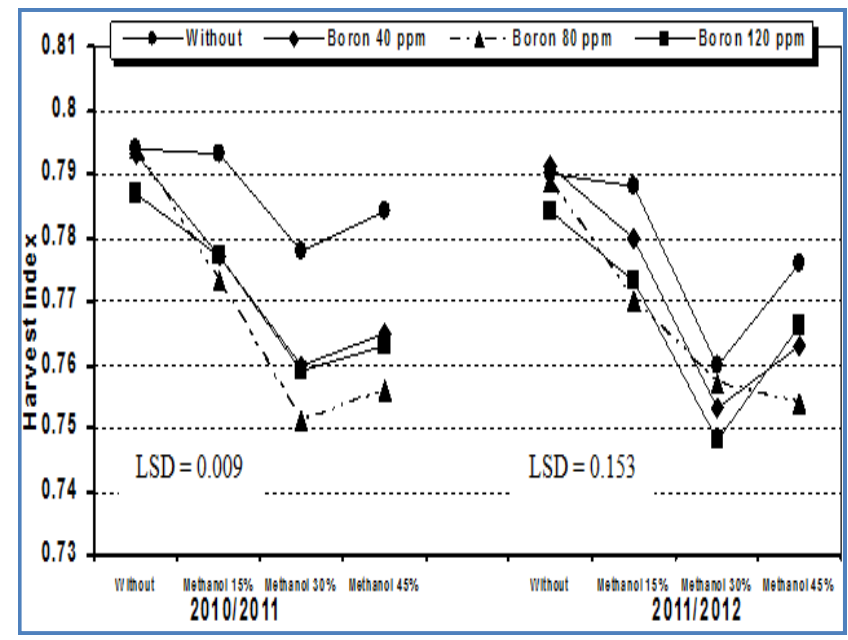

Fig. 11- Harvest index of sugar beet as affected by the interaction between methanol and boron treatments during 2010/2011 and 2011/2012 seasons

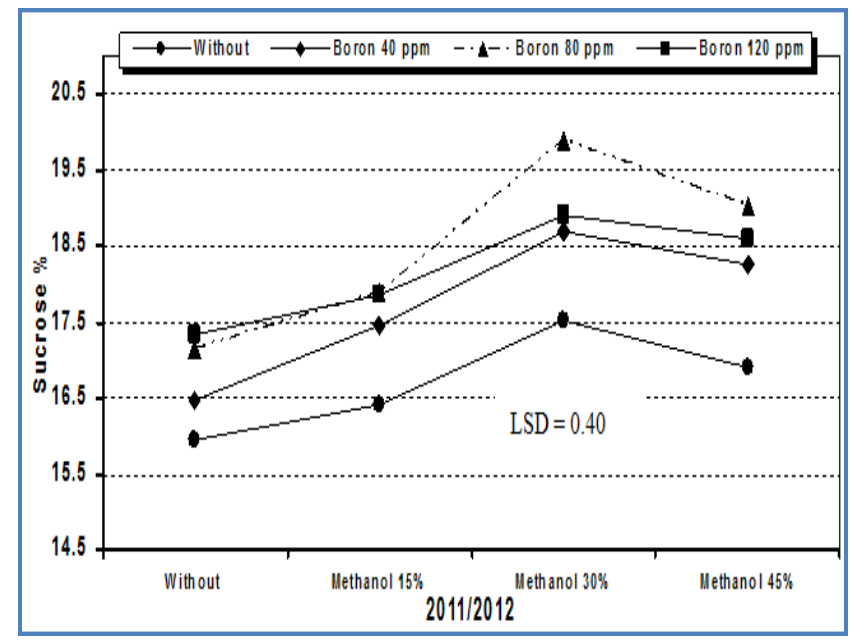

Fig. 12- Sucrose $\%$ of sugar beet as affected by the interaction between methanol and boron treatments during 2011/2012 season. 


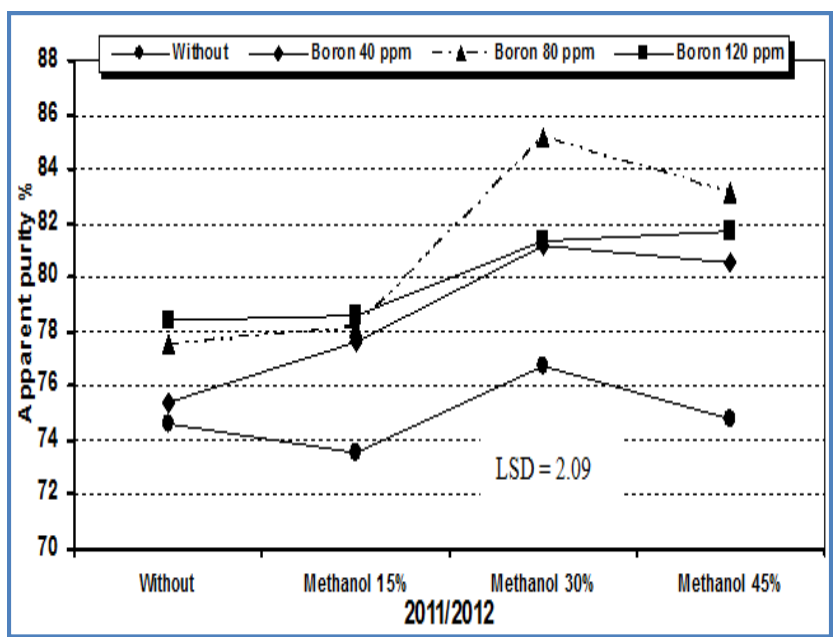

Fig. 13- Apparent purity $\%$ of sugar beet as affected by the interaction between methanol and boron treatments during 2011/2012 season.

It could be stated that highest averages of total chlorophyll, leaf area/plant, foliage and root fresh weight, foliage and root length, root diameter, sucrose (\%), apparent purity percentages (\%), top and root yield, sugar yield were obtained from foliar spraying of $30 \%$ methanol and $80 \mathrm{ppm}$ boron. On the other hand, highest values of harvest index were recorded due to the interaction without methanol spraying.

It could be recommended that to maximize sugar beet yields and root quality achieved by foliar spraying $30 \%(\mathrm{v} / \mathrm{v})$ methanol and 80 ppm boron.

\section{References}

[1] Abdel-Latif A., Schmieden U., Barakat S. and Wild A. (1996) Plant Physiology and Biochemistry, Spec. Issue, 133.

[2] Andres A.R., Lazaro J.J., Chueca A., Hermoso R. and Gorge J.L. (1990) Physiologia Plantarum, 78, 409-413.

[3] Armin M. and Asgharipour M.R. (2012) American-Eurasian J. Agric. \& Environ. Sci., 12(4), 444-448.

[4] Brown P.H. and Hu H. (1996) Ann. Botany, 77, 497-505.

[5] Carruthers A. and Oldfield J.E.T. (1960) Int. Sugar J., 63, 7274.

[6] Desclaux D., Huynh T.T. and Roumet P. (2000) Crop Sci., 40, 716-722.

[7] Dordas C., Apostolides G.E. and Goundra O. (2007) J. of Agric. Sci., 145, 377-384.

[8] Gerendas J. and Sattelmatcher B. (1990) Plant Nutration Physiology and Application, 33-37.

[9] Gezgin S., Hamurcu M. and Apaydin M. (2001) Turkish J. of Agric. and Forestry, 25, 89-95.

[10]Gobarah Mirvat E. and Mekki B.B. (2005) J. of Applied Sci. Res., 1(5), 373-379.

[11]Gomez K.N. and Gomez A.A. (1984) Statistical Procedures for Agricultural Research, 2nd Ed., John Wiley \& Sons, Inc., New York, 95-109.
[12]Gout E., Aubert S., Bligny R., Rébeillé F., Nonomura A.R., Benson A.A. and Douce R. (2000) Plant Physiology, 123, 287296.

[13]Hellal F.A., Taalab A.S. and Safaa A.M. (2009) Ozean J. of Applied Sci., 2(1), 1-10.

[14]Kristek A., Stojic B. and Kristek S. (2006) Agriculture-Scientific and Professional Review, 12(1), 22-26.

[15]Lee H.S., Madhaiyan M., Kim C.W. Choi S.J., Chung K.Y. and Sa T.M. (2006) Biology and Fertility of Soils, 42, 402-408.

[16]Loomis W.D. and Durst R.W. (1992) BioFactors, 3, 229-239.

[17]Makhdum M.I., Malik M.N.A., Din S.U., Ahmad F. and Chaudhry F.I. (2002) Journal of Researches in Sci., 13, 37-43.

[18]Nadali I., Paknejad F., Moradi F., Vazan S., Tookalo M., Jami Al-Ahmadi M. and Pazoki A. (2010) Australian J. of Crop Sci., 4 (6), 398-401.

[19]Nonomura A.M. and Benson A. (1992) Proceedings of National Academy of Science, USA, 89, 9794-9798.

[20]Sadeghi-Shoae M., Paknejad F., Kashani A., Vazan S. and Nooralvandi T. (2012) Resilience of Agricultural Systems Against Crises, Tropentag, Gottingen- Kassel/Witzenhausen.

[21]Snedecor G.W. and Cochran W.G. (1980) Statistical Methods, 7th ed., USA.

[22]Tersahima I.and Evans J.R. (1988) Plant Cell Physiol., 29, 143155.

[23]Zbieć I. and Karczmarczyk S. (1997) Romanian Agricultural Res., 7-8, 45-49.

[24]Zbieć I., Karczmarczyk S. and Podsiadlo C. (2003) ElectronicJournal of Polish Agricultural Universities, Agronomy, 6, 1-7.

[25]Zbieć I.I., Karczmarczyk S. and Koszański Z. (1999) Folia Universitatis Agriculturae Stetinensis, Agricultura, 73, 217-220. 